\title{
Mesozoic evolution of West Antarctica and the Weddell Sea Basin: new paleomagnetic constraints
}

\author{
A.M. Grunow, D.V. Kent and I.W.D. Dalziel * \\ Lamont-Doherty Geological Observatory and Department of Geological Sciences of Columbia University, Palisades, NY 10964 (U.S.A.)
}

Received March 2, 1987; revised version received July 27, 1987

\begin{abstract}
Paleomagnetic data from the Antarctic Peninsula and our recent results from the Ellsworth-Whitmore Mountains block suggest that since the Middle Jurassic these two West Antarctic blocks have undergone little relative movement and together have rotated relative to the East Antarctic craton. New data from Lower Cretaceous rocks from the Thurston Island region of West Antarctica suggest that on the basis of paleomagnetic constraints, the Antarctic Peninsula, Ellsworth-Whitmore Mountains and Thurston Island blocks define a single entity which we call Weddellia; some motion between these blocks is possible within the limits of the paleomagnetic data.

Between the Middle Jurassic and Early Cretaceous, Weddellia remained attached to West Gondwanaland while East Antarctica moved southward (dextrally) relative to Weddellia. From the Early Cretaceous to mid-Cretaceous, Weddellia rotated clockwise $30^{\circ}$ and moved sinistrally approximately $2500 \mathrm{~km}$ relative to East Antarctica, to its present-day position. We suggest the Early to mid-Cretaceous to be the time of the main if not initial opening of the Weddell Sea.
\end{abstract}

\section{Introduction}

Reconstructions of Gondwanaland have always been hampered by the uncertainty in positioning West Antarctica [1-3]. Based on geological and geophysical arguments, West Antarctica can be divided into discrete structural blocks that form topographic highs [4-8]: the Antarctic Peninsula block (AP); the Ellsworth-Whitmore Mountains block (EWM); the Haag Nunataks block $(\mathrm{H})$; the Thurston Island-Eights Coast block (TI); and Marie Byrd Land (MBL) (Fig. 1).

Geologically, West Antarctica is quite different from East Antarctica in that the rocks consist primarily of Mesozoic and Cenozoic subduction related instrusives and extrusives (AP, TI and MBL blocks); deformed Paleozoic sedimentary rocks (EWM and MBL blocks); and Middle Jurassic granites (EWM block) [6]. The Haag Nunataks are unique because they represent the

Lamont-Doherty Geological Observatory Contribution \# 4180 .

* Now at University of Texas at Austin, Institute for Geophysics, Austin, TX 78759, U.S.A. only known Precambrian basement in West Antarctica [7]. East Antarctica consists mostly of Precambrian shield, Paleozoic sedimentary and intrusives rocks (the Transantarctic Mountains) and Middle Jurassic mafic igneous rocks [9].

Available paleomagnetic data from the West Antarctic blocks, except the $\mathrm{H}$ block where there are no data; indicates motion of these blocks relative to East Antarctica [10-14]. It has been suggested that the EWM block should be rotated $90^{\circ}$ relative to East Antarctica because this would align the structural trends of the Ellsworth Mountains sedimentary rocks with the East Antarctic Transantarctic Mountains sedimentary rocks [4,5]. Cambrian paleomagnetic data [10] from the EWM block support a $90^{\circ}$ clockwise restorative rotation relative to East Antarctica but the timing and even the sense of this rotation is not well established.

The geologic history of the EWM and TI blocks was reexamined using geochronology, geochemistry, structural analysis, sedimentology and paleomagnetism by the joint British Antarctic Survey-United States Antarctic Research Program West Antarctic Tectonics project [7,15-19]. The paleomagnetic results from the TI block are presented here and interpreted in conjunction with 


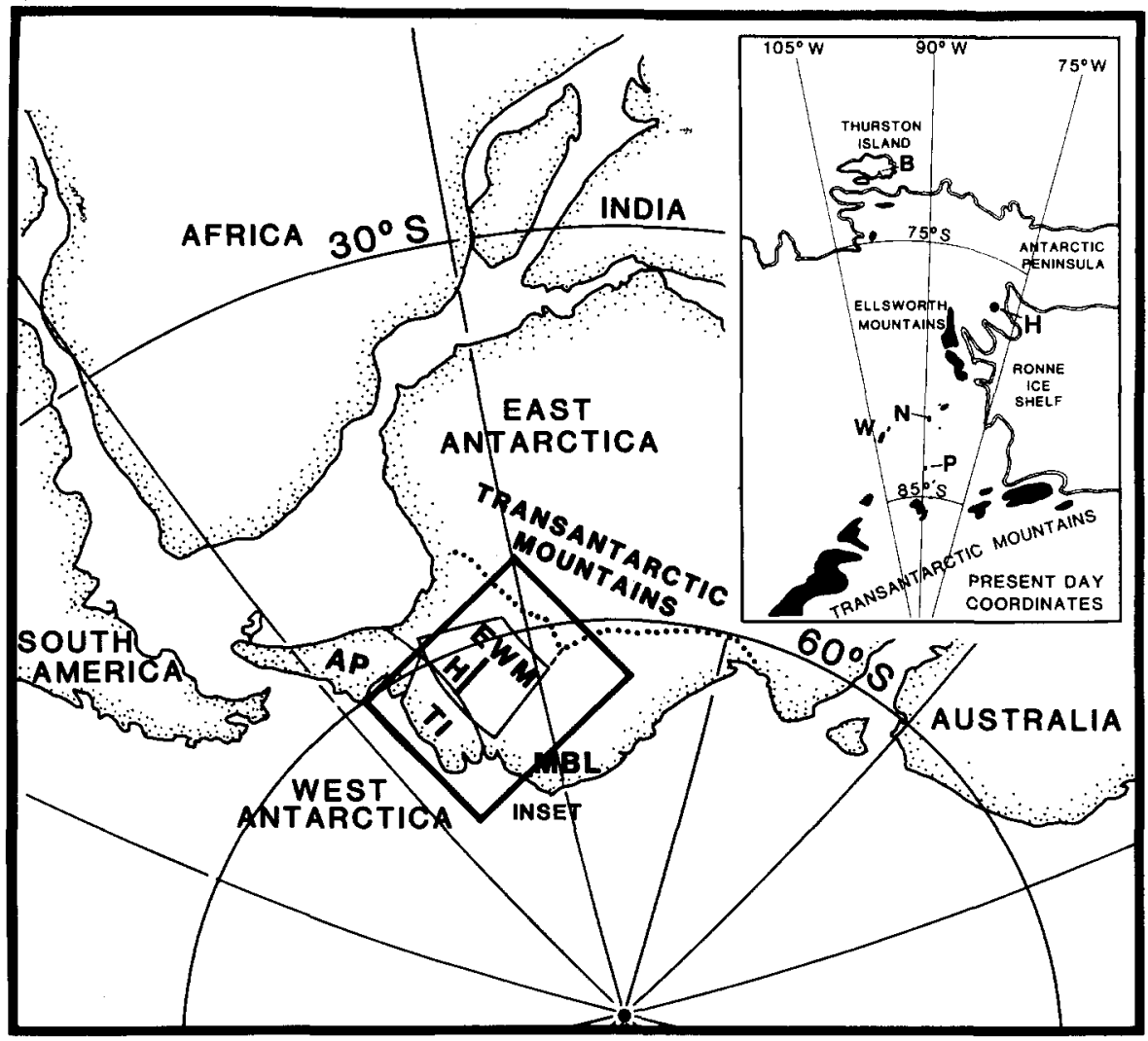

Fig. 1. Gondwanaland reconstruction by Norton and Sclater [3]. West Antarctic crustal blocks [4-8]: $A P=$ Antarctic Peninsula; $E W M=$ Ellsworth Mountains-Whitmore Mountains; $H=$ Haag Nunataks; $M B L=$ Marie Byrd Land; $T I=$ Thurston Island-Eights Coast. Inset shows sample localities in the EWM and TI crustal blocks: $B=$ Belknap and adjoining unnamed nunatak: $H=H a a g$ Nunataks; $N=$ Nash Hills; $P=$ Pagano Nunatak; $W=$ Whitmore Mountains.

our earlier reported results [14] from the EWM block.

\section{Sampling}

An extensive collection of paleomagnetic cores was obtained from the EWM (480 cores, 77 sites) and TI (728 cores, 114 sites) blocks by West Antarctic Tectonics Project during the 1983-84 and 1984-85 field seasons. Cores were collected by using a gasoline powered, portable diamond-bit coring drill and oriented with a Brunton compass. Sun compass readings were taken at all localities to correct for local magnetic variation. A wide variety of rocks (intrusive, sedimentary and metamorphic), ranging in age from Pre-Cambrian to Jurassic, were samples from the EWM blocks. Paleozoic (?) and Mesozoic plutons, Mesozoic and
Tertiary volcanics, dikes and metamorphic rocks were samples from the TI block. In the case of the igneous rocks an effort was made to collect sites with a variety of textures within individual rock units in the hope that these would have somewhat different cooling histories, hence averaging the effects of secular variation.

Pilot samples from most sites were subjected to demagnetization experiments but special effort was made on the Jurassic units because: (1) a Middle Jurassic paleopole is available for the AP block [13]; (2) dated or presumed Middle Jurassic rocks were samples from both the EWM $[16,20]$ and TI blocks; (3) reference poles for the Middle Jurassic are available from East Antarctica (Ferrar dolerites) $[21,22]$; (4) these reference Jurassic paleopoles for East Antarctica are located in middle latitudes, exceptional for at least late Paleozoic 
to Recent time during which the apparent polar wander path tends to be in very high latitudes. Thus, relative rotations can be more readily resolved in the Jurassic than for any other time in this interval using paleomagnetic data.

\section{Previous paleomagnetic results}

Our paleomagnetic results from the EWM block have been presented elsewhere [14]. Briefly, Middle Jurassic coarse-grained, peraluminous granitic plutons from the Pagano Nunatak and Nash Hills (Fig. 1) ( Rb/Sr whole rock ages of $175 \pm 8$ m.y. and $175 \pm 8$ m.y., respectively) [16] gave stable normal and reversed directions that are antipodal. The Pagano sites have normal polarity whereas the Nash Hills sites have predominantly reversed polarity, except near the margin where baked metasedimentary rocks were magnetically overprinted with a stable normal-polarity direction also found in the granite near the contact. The combined paleopole determined from 8 sites from these 2 localities that are $200 \mathrm{~km}$ apart is $235.2^{\circ} \mathrm{E}$, $41.2^{\circ} \mathrm{S}\left(A_{95}=5.3^{\circ}, K=110.2\right)$; a paleolatitude of $47^{\circ} \mathrm{S}$ is indicated for this area of the EWM block. This pole is not significantly different from the Middle Jurassic pole from the AP block [13] but is significantly different from the mean East Antarctic Middle Jurassic pole recalculated by us [14] $\left(220.3^{\circ} \mathrm{E}, 54.9^{\circ} \mathrm{S}, A_{95}=3.9^{\circ}, K=97.2, N=\right.$ 15 localities) (Table 1). In the Nash Hills Cambrian(?) metasedimentary rocks a component of magnetization stable after thermal demagnetization above $560^{\circ}$ yielded mean tilt corrected directions of $D=21.2^{\circ}, I=0.8^{\circ}, \alpha_{95}=8.4^{\circ}, k=$ 27.6, $n=12$ samples ( 2 sites), corresponding to a pole located at $292^{\circ} \mathrm{E}, 7.2^{\circ} \mathrm{N}$. This pole is very similar to the Late Cambrian pole $\left(296^{\circ} \mathrm{E}, 4^{\circ} \mathrm{N}\right)$ from the Ellsworth Mountains Heritage Group [10] and suggests that little relative rotation occurred within the EWM block.

\section{New paleomagnetic results}

New paleomagnetic data are presented here for the TI block. A dioritic to gabbroic intrusion and cross-cutting mafic and granitic dikes forming Belknap Nunatak and an unnamed nunatak $(5 \mathrm{~km}$ to the south) were selected for detailed paleomagnetic study (Fig. 1). The intrusive body was thought tentatively to be Jurassic (160 Ma) based on an early $\mathrm{K}$-Ar determination on a pyroxene separate (C. Craddock, personal communication, 1985), but $\mathrm{Rb} / \mathrm{Sr}$ whole rock dating has now yielded an Early Cretaceous isochron of $122 \pm 2 \mathrm{~m}$.y. for the entire igneous complex (I. Millar and R. Pankhurst, personal communication, 1986). A total of 47 independently oriented core samples from 8 sites were drilled at these 2 nunataks. Sun compass readings at each locality required corrections of $<3^{\circ}$ to the magnetic declinations.

The natural remanent magnetization (NRM) of the samples was measured on either a cryogenic magnetometer or a computerized fluxgate spinner magnetometer. NRM intensities ranged between $10^{1}$ and $10^{2} \mathrm{~A} / \mathrm{m}$, typically higher in the more mafic lithologies. Samples were progressively demagnetized in a minimum of 5 steps up to a peak alternating field (AF) of $100 \mathrm{mT}$. The demagnetization data were plotted on vector end-point diagrams [23] and characteristic directions were calculated by using principal component analysis [24].

A single component of magnetization, upward

TABLE 1

Paleomagnetic poles

\begin{tabular}{|c|c|c|c|c|c|c|}
\hline Location & Age (Ma) & Long. $\left({ }^{\circ} \mathrm{E}\right)$ & Lat. $\left({ }^{\circ} \mathrm{S}\right)$ & $K$ & $A_{95}$ & Reference \\
\hline AP block & 175 & 238.0 & 48.0 & - & 9.5 & [8] \\
\hline EWM block & 174 & 235.2 & 41.2 & 110.2 & 5.3 & [9] \\
\hline \multicolumn{7}{|l|}{ Combined Middle } \\
\hline Jurassic AP-EWM mean pole & 175 & 237.0 & 45.8 & 111.5 & 6.4 & [9] \\
\hline East Antarctica & $160-180$ & 220.3 & 54.8 & 97.2 & 3.9 & [8] \\
\hline TI block & 122 & 232.0 & 49.0 & 233.1 & 7.9 & this paper \\
\hline
\end{tabular}

$K=$ estimation of Fisher's [43] precision parameter; $A_{95}=$ radius of circle at the $95 \%$ confidence level for mean pole position. 
pointing to the southwest, was consistently found in 5 sites at the unnamed nunatak and 1 site at Belknap Nunatak (total of 34 samples; Fig. 2a and b). The magnetizations at these 6 sites are of normal polarity and very high stability. Since the
TI19C 2A

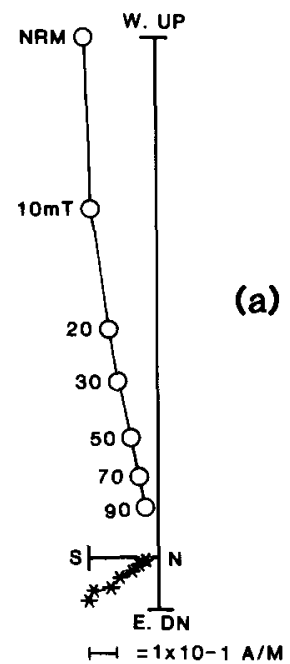

TI20B 5A

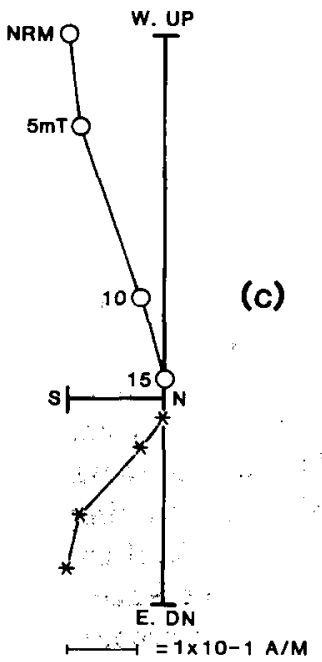

TI19E 6A

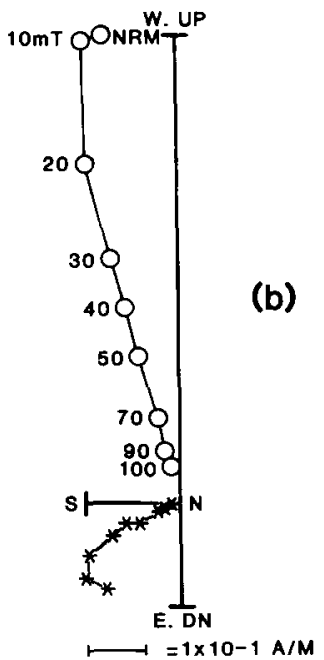

TI2OC 1

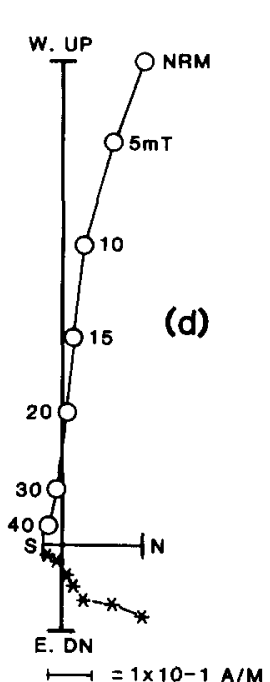

Fig. 2. Orthogonal projection of vector end-points [17] showing demagnetization behavior of samples from Belknap Nunatak and the unnamed nunatak. Open circles (stars) are projection on vertical (horiziontal) planes at indicated levels (in $\mathrm{mT}$ ) of AF cleaning. (a) Diorite from unnamed nunatak. (b) Granitic dike from unnamed nunatak. (c) Low-coercivity mafic dike from Belknap nunatak. (d) Overprinted fine-grained gabbro from Belknap Nunatak. directions depart from the present-day field and only a single component is present, we assume that this is an original magnetization acquired during cooling. Three different rock units (diorite/gabbro, a diabase dike and a 5-m-wide granitic dike with xenoliths of the diorite) gave the same directions. Although the precise time elapsed between emplacement of these various lithologies is not known, it seems reasonable to assume that sufficient time is represented to average the effects of secular variation.

Two of the 8 sites proved unsuitable for the final analysis. These sites (12 samples) are dominated by very low coercivity components, the samples typically retaining less than $10 \%$ of their original intensity at $20 \mathrm{mT}$ (Fig. 2c). Several samples contained a partial magnetic overprint component that was oriented northeast and upward pointing (Fig. 2d), but a more stable, possibly primary component could not be adequately resolved because it was retained only in the last $5-10 \%$ of the magnetization.

Our unit mean direction of $D=133.7^{\circ}, I=$ $-75.6^{\circ}, \alpha_{95}=4.4^{\circ}, k=233.1$, for the TI block was determined by combining sample means (Fig. 3 ) to produce 6 site means; the 6 site means were combined to produce the unit mean (Table 2).

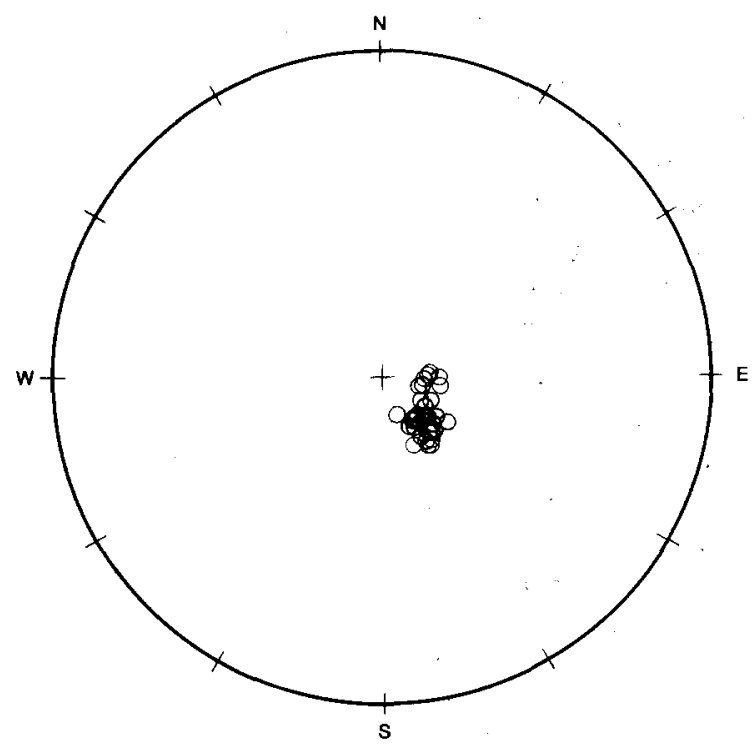

Fig. 3. Equal area projection of characteristic cleaned mean sample directions from Belknap Nunatak and unnamed nunatak. Open symbols are on the upper hemisphere. 1 sample rejected from 35 samples. 
TABLE 2

Belknap Nunatak and unnamed nunatak $\left(72^{\circ} 26^{\prime} \mathrm{S}, 97^{\circ} 45^{\prime} \mathrm{W}\right)$

\begin{tabular}{|c|c|c|c|c|c|c|c|c|}
\hline \multirow[t]{2}{*}{ Site } & \multirow[t]{2}{*}{ Lithology } & \multirow[t]{2}{*}{$n / N$} & \multirow[t]{2}{*}{$D\left({ }^{\circ}\right)$} & \multirow[t]{2}{*}{$I\left(^{\circ}\right)$} & \multirow[t]{2}{*}{$k$} & \multirow[t]{2}{*}{$\alpha_{95}\left(^{\circ}\right)$} & \multicolumn{2}{|l|}{ Pole } \\
\hline & & & & & & & long. $\left({ }^{\circ} \mathrm{E}\right)$ & lat. $\left({ }^{\circ} S\right)$ \\
\hline TI19A & layered gabbro & $6 / 6$ & 93.9 & -78.1 & 1009.8 & 2.1 & 210.4 & 60.6 \\
\hline TI19B & mafic dike & $6 / 6$ & 145.2 & -70.3 & 1162.5 & 2.0 & 236.9 & 39.1 \\
\hline TI19C & diorite/gabbro & $6 / 6$ & 132.1 & -75.7 & 625.1 & 2.7 & 231.2 & 49.2 \\
\hline TI19D & diorite & $4 / 4$ & 141.9 & -73.7 & 888.4 & 3.1 & 236.3 & 44.6 \\
\hline TI19E & granitic dike & $5 / 6$ & 143.2 & -75.1 & 1173.3 & 2.2 & 238.0 & 46.7 \\
\hline TI20A & diorite & $7 / 7$ & 130.9 & -77.2 & 288.3 & 3.6 & 231.9 & 51.8 \\
\hline Mean & $N=6$ sites & $34 / 35$ & 133.7 & -75.6 & 233.1 & 4.4 & 232.0 & $A_{9 \mathrm{~S}}=7.9^{\circ}$ \\
\hline
\end{tabular}

$n / N=$ number of samples used in site mean calculation/total number of samples; $k=$ estimation of Fisher's [43] precision parameter; $\alpha_{95}=$ radius of error circle at the $95 \%$ confidence level; $A_{95}=$ radius of circle at the $95 \%$ confidence level for the mean pole position; the mean paleopole position is derived from the 6 individual poles.

This direction corresponds to an Early Cretaceous paleomagnetic south pole for the TI block at $232^{\circ} \mathrm{E}, 49^{\circ} \mathrm{S}\left(A_{95}=7.9^{\circ}, K=72.9\right)$ for $N=6$ site mean virtual geomagnetic poles (Table 1) and a paleolatitude of $62.8^{\circ} \mathrm{S}$. The TI pole falls near the Middle Jurassic EWM $\left(235,2^{\circ} \mathrm{E}, 41.2^{\circ} \mathrm{S}\right)$ and $\operatorname{AP}\left(238^{\circ} \mathrm{E}, 48^{\circ} \mathrm{S}\right)$ poles, even though it is younger by $50 \mathrm{~m} . \mathrm{y}$.

\section{Discussion of paleomagnetic results}

There are three possibilities to explain the close correspondence of the Early Cretaceous TI pole with the AP and EWM Middle Jurassic poles: (1) the TI rocks by tectonic or intrusive activity have been tilted in just such a way to make an (unknown) Early Cretaceous paleomagnetic direction correspond to the Middle Jurassic one in the AP and EWM blocks; (2) the TI rocks have not been tilted but the TI block moved separately from AP and EWM blocks such that the correspondence of paleopoles is coincidental, (3) the paleomagnetic pole was nearly stationary from the Middle Jurassic to the middle Early Cretaceous with respect to all three structural blocks.

The first explanation (tilting) is a possibility difficult to disprove. Tilt corrections have not been applied in any of the West Antarctic studies because the poles have been determined by analysis of intrusive rocks for which the paleohorizontal cannot be documented. However, the remarkable similarity in the AP and EWM poles, obtained from very similar age rocks sampled over a large region, implies to us that little tilting has occurred in these areas. Indeed, the structure of the Paleozoic sedimentary country rocks of the EWM block as a whole indicates no positive evidence for tilting since the emplacement of the paleomagnetically identical Nash Hills and Pagano Nunatak plutons. The folds are upright, the hinge lines are sub-horizontal [17]. At present, there are no other Early Cretaceous poles (pre-122 Ma) from East or West Antarctica to compare with the TI pole. Nonetheless, we feel that it would be unlikely that the TI rocks would be tilted just the right amount and about the right axis for the stable magnetic directions to end up nearly the same as the Middle Jurassic directions from the AP and EWM blocks.

The second possibility (a location for the TI block exotic to West Antarctica and East Antarctica) places the TI block as an isolated entity somewhere in the Pacific west of southern South America or perhaps adjacent to East Gondwanaland (Australia). Definitive geologic arguments cannot be made to support or reject this possibility, although the rocks of the TI block, including those sampled, are not unlike the rocks of the Mesozoic-Cenozoic magmatic arc forming the presently adjoining Antarctic Peninsula. If exotic, the TI block would have had to experience a rather fortuitous plate motion history to account for the coincidence in paleopoles.

The third and favored explanation (little apparent polar wander) for the very close similarity in the Early Cretaceous TI pole and the Middle Jurassic AP and EWM poles accepts the data at 
face value and incorporates the conservative assumption that the TI block remained part of the tectonic unit formed by the AP and EWM blocks, i.e., the AP-EWM-TI blocks were essentially one paleomagnetic entity between at least 175 and 122 m.y. ago. The Precambrian Haag Nunataks have been left in their present relative position with respect to the AP and EWM blocks because it is a geologically acceptable position [8] and there are no paleomagnetic data to support an exotic location. We propose to call this group of geologically and paleomagnetically related blocks, Weddellia [25]. Indirect arguments must be made for Weddellia's existence since there are no Middle Jurassic TI poles and no middle Early Cretaceous AP or EWM poles, i.e., no poles of similar age common to all three structural blocks exist to allow a paleomagnetic test.

\section{Plate tectonic setting}

In considering the tectonic setting of Weddellia during the Jurassic and Cretaceous, we have chosen to use the Norton and Sclater [3] reconstruction of Gondwanaland because their reconstruction fits the Gondwanaland paleomagnetic data closely [27] and provides the necessary rotation poles. Recent refinements of the Gondwanaland reconstruction [28] do not appreciably affect our position for Weddellia and would require using several different sources to obtain all of the rotation poles. We have determined a mean paleomagnetic pole for Africa, Australia and East Antarctica for the period 165-180 Ma. This more precisely coincides with the age of the AP-EWM Middle Jurassic poles, compared to the Gondwanaland paleopole for the Triassic and Jurassic periods combined calculated by Norton and Sclater [3]. We have excluded South American poles from the analysis of Gondwanaland mean poles because Mesozoic poles from South America tend to fall very close to the present-day field [27], making it difficult to distinguish between Mesozoic paleomagnetic directions and present-day overprints in the absence of appropriate fold tests.

There are seven African paleomagnetic poles that fall within the prescribed age constraints [29] giving a mean Middle Jurassic pole for Africa at $77.7^{\circ} \mathrm{E}, 65.2^{\circ} \mathrm{S} \quad\left(A_{95}=5.1^{\circ}, K=138.6\right)$. Two Middle Jurassic poles from Australia [27] yield a mean paleomagnetic pole at $180.5^{\circ} \mathrm{E}, 51.1^{\circ} \mathrm{S}\left(A_{95}\right.$ $=15.1^{\circ}, K=249.3$ ); the study of the Kangaroo Island Basalts [30] was excluded because it is based on only two sites. For East Antarctica, we use the Middle Jurassic pole listed earlier which is based on 15 separate studies $\left(220.3^{\circ} \mathrm{E}, 54.9^{\circ} \mathrm{S}\right)$.

Using Norton and Sclater's finite rotation poles for closure and rotating the Middle Jurassic poles for Australia and Africa into an Antarctic reference frame, we found that the mean Middle Jurassic paleomagnetic pole of these continents is well defined at $219.7^{\circ} \mathrm{E}, 56.8^{\circ} \mathrm{S},\left(A_{95}=3.1^{\circ}, K=\right.$ 1550 , for $N=3$ ). This close agreement of poles indicates that the Norton and Sclater reconstruction provides a good general description of the predrift configuration of Gondwanaland, for a time when the position of East Gondwanaland (Australia, East Antarctica, India) to West Gondwanaland (Africa and South America) is not well constrained by sea-floor data.

The only Gondwanaland poles of similar age to the TI block (130 Ma to $110 \mathrm{Ma}$ ) come from Africa [27]. African middle Early Cretaceous poles [29] $\left(83^{\circ} \mathrm{E}, 56.6^{\circ} \mathrm{S}, A_{95}=11.9^{\circ}, K=108, N=3\right)$ are not significantly different from the African Middle Jurassic ones, i.e., little apparent polar wander has occurred between about 180 and 110 Ma. This is consistent with our assumption that Weddellia had remained part of West Gondwanaland from the Middle Jurassic to the Early Cretaceous.

\section{New tectonic models}

Weddellia's tectonic evolution during the Middle Jurassic and Early Cretaceous has been divided into two scenarios: (1) rigid Weddellia-no relative motion between the AP-EWM-TI blocks; (2) mosaic Weddellia-motion allowed between the AP-EWM-TI blocks. Paleomagnetically we cannot distinguish between these possibilities of Weddellia's Mesozoic plate motion history and believe that the actual evolution of Weddellia could lie somewhere between the two models.

The first scenario assumes that there has been virtually no relative motion between the AP, EWM and TI blocks. Rigid Weddellia's 175 Ma position is shown in Fig. 4a, based on the combined APEWM Middle Jurassic pole of $237^{\circ} \mathrm{E}, 45.8^{\circ} \mathrm{S}$ ( $A_{95}=6.4^{\circ}, K=111.5, N=6$ localities), and is 

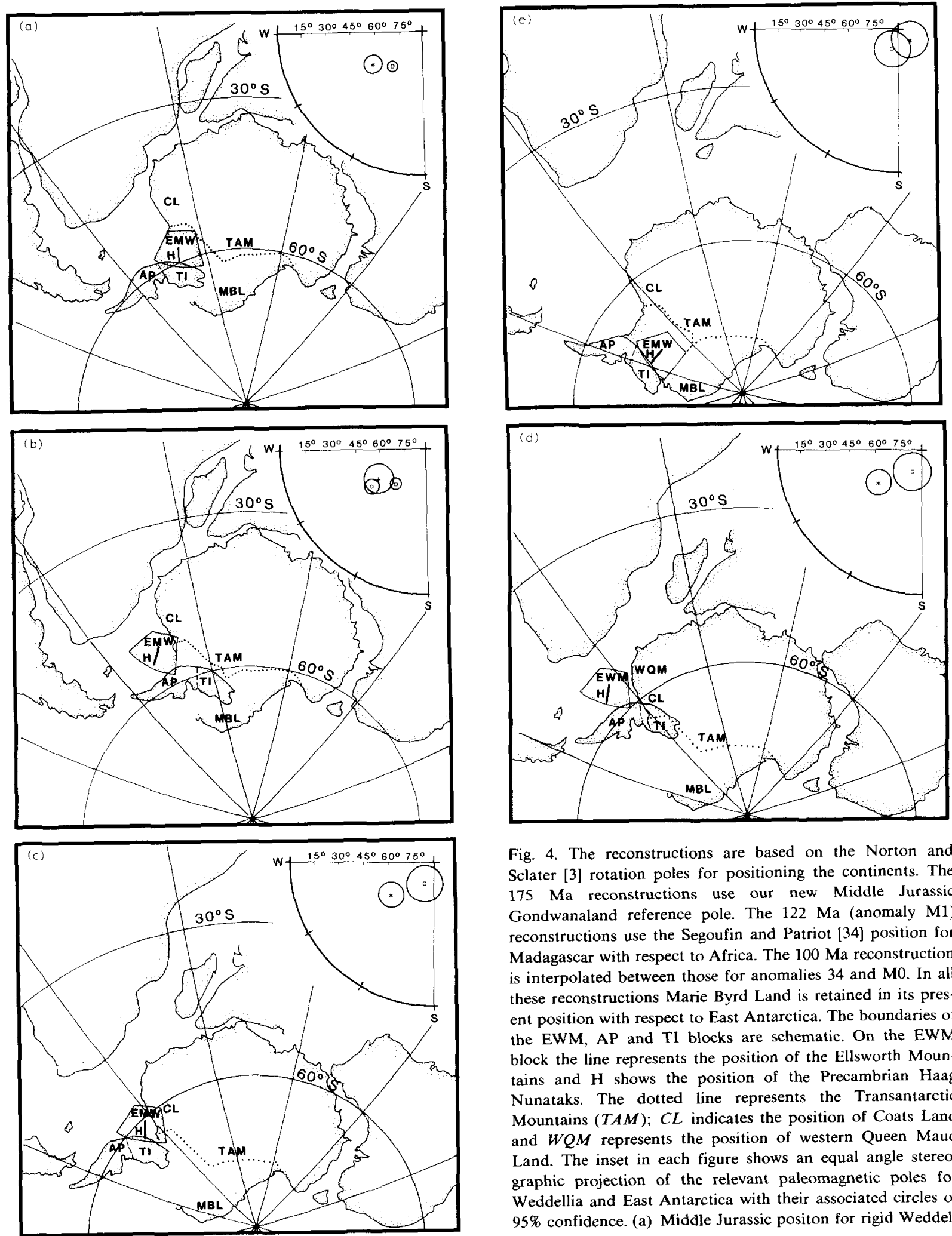

Fig. 4. The reconstructions are based on the Norton and Sclater [3] rotation poles for positioning the continents. The $175 \mathrm{Ma}$ reconstructions use our new Middle Jurassic Gondwanaland reference pole. The $122 \mathrm{Ma}$ (anomaly M1) reconstructions use the Segoufin and Patriot [34] position for Madagascar with respect to Africa. The $100 \mathrm{Ma}$ reconstruction is interpolated between those for anomalies 34 and M0. In all these reconstructions Marie Byrd Land is retained in its present position with respect to East Antarctica. The boundaries of the EWM, AP and TI blocks are schematic. On the EWM block the line represents the position of the Ellsworth Mountains and $H$ shows the position of the Precambrian Haag Nunataks. The dotted line represents the Transantarctic Mountains (TAM);CL indicates the position of Coats Land and $W Q M$ represents the position of western Queen Maud Land. The inset in each figure shows an equal angle stereographic projection of the relevant paleomagnetic poles for Weddellia and East Antarctica with their associated circles of $95 \%$ confidence. (a) Middle Jurassic positon for rigid Weddel- 
constrained by the observed paleolatitudes at the sample localities in the AP and EWM blocks of $54^{\circ} \mathrm{S}$ and $47^{\circ} \mathrm{S}$, respectively. The limits of the paleomagnetic error must be used to avoid the apparent overlap of the AP block with South America forced by the paleolatitude constraints of the AP and EWM blocks. The predicted overlap could largely be due to widespread extension of continental crust in South America and/or rigid Weddellia after the emplacement of the AP and EWM plutons on which the poles are based, rather than with major problems in the Gondwanaland reference poles $[3,31,32]$. This reconstruction also uses the maximum amount of rotation allowed by the paleomagnetic data to achieve the more northerly position of the EWM block. The Ellsworth Mountains structural trend strikes at high angle into East Antarctica, south of Coats Land in Fig. 4a.

An alternative Middle Jurassic reconstruction (mosaic Weddellia) more exactly restores the individual mean paleopoles from the AP and EWM

lia i.e., little relative motion between the AP, EWM and TI blocks. Equal angle plot shows rigid Weddellia mean pole (*) and East Antarctic mean pole (ㅁ). (b) Middle Jurassic position for mosaic Weddellia i.e., uses the individual AP and EWM paleomagnetic poles. Equal angle projection shows individual mean poles of the AP block $(+)$, EWM block $(O)$ and East Antarctica ( $\square$ ). (c) The 122 Ma position for a rigid Weddellia using the TI paleomagnetic pole. Note the dextral strike-slip motion $(\approx 650 \mathrm{~km}$ ) required along the EWM/East Antarctica boundary since the Middle Jurassic. Equal angle plot for rigid Weddellia: mean Early Cretaceous paleopole for Weddellia (*) and East Antarctica ( $\square$ ); the East Antarctic pole was obtained by rotating the African mean Early Cretaceous pole $\left(83^{\circ} \mathrm{E}\right.$, $56.6^{\circ} \mathrm{S}$ ) into East Antarctic coordinates. (d) The $122 \mathrm{Ma}$ position for mosaic Weddellia. Note the dextral strike-slip motion $(\approx 650 \mathrm{~km}$ ) required along the EWM/East Antarctica and TI/East Antarctica boundaries since the Middle Jurassic. Equal angle plot for Early Cretaceous mosaic Weddellia: the TI block pole represents Weddellia (*) and the African Early Cretaceous mean pole rotated into East Antarctic coordinates represents the East Antarctic paleopole (D). (e) At $100 \mathrm{Ma}$, Weddellia was in its present-day position with respect to East Antarctica. Note the $\approx 2500 \mathrm{~km}$ of sinistral strike-slip motion needed along the EWM/East Antarctica boundary and a clockwise rotation of $\approx 30^{\circ}$ relative to East Antarctica since $122 \mathrm{Ma}$. Dextral strike-slip motion is needed between the AP-TI/EWM blocks since $122 \mathrm{Ma}$ in the case of the mosaic Weddellia reconstruction (Fig. 4d). Equal angle plot shows the mid-Cretaceous mean paleopoles for Weddellia (*) based on the AP block pole [38] and East Antarctica ( $\square$ ) based on the Australian mean mid-Cretaceous pole $\left(153^{\circ} \mathrm{E}, 52^{\circ} \mathrm{S}\right)$ [27] rotated into East Antarctic coordinates. blocks to the mean Gondwanaland pole. This forces the AP and EWM blocks to move as separate but adjacent structural units (Fig. 4b). The Ellsworth Mountain sedimentary succession would then strike into the continental shelf adjacent to Coats Land.

Between about 155 and $122 \mathrm{Ma}$, East Gondwanaland (including East Antarctica) moved south by approximately $650 \mathrm{~km}$ with respect to West Gondwanaland (including Weddellia) as a result of the opening of the Somali and Mozambique basins [32-36] (Fig. 4c and d). Unacceptable overlap between the EWM and AP-TI blocks is created if, during this interval, the EWM block moved with East Antarctica rather than with the AP and TI blocks. Hence, either a rigid or a mosaic Weddellia remained essentially fixed with respect to West Gondwanaland during this time. The position of Weddellia's EWM block relative to East Antarctica changed along a dextral transform zone, either starting south of Coats Land and ending up adjacent to Coats Land (Fig. 4a and c) or starting near Coats Land and ending up adjacent to western Queen Maud Land (Fig. 4b and $\mathrm{d}$ ). If Weddellia was not a rigid tectonic entity, an equivalent amount of dextral transcurrent motion would be required along the AP/TI boundary with East Antarctica between the Middle Jurassic (Fig. 4b) and the Early Cretaceous (Fig. 4d).

Paleomagnetic data from mid- to Late Cretaceous rocks of the Antarctic Peninsula [37,38] suggest that the AP block, and hence we assume the rest of Weddellia, had moved to its present-day position relative to East Antarctica by about 100 m.y. ago. This leaves approximately $22 \mathrm{~m} . \mathrm{y}$. for either rigid or mosaic Weddellia to have moved from its middle Early Cretaceous (122 Ma; ca. M1 time [39]) position in Fig. $4 c$ or $d$, to the mid-Cretaceous (100 Ma) one in Fig. 4e. We suggest this motion may be associated with the main opening of the Weddell Sea. An older age for the opening has been previously suggested on the basis of magnetic anomalies in the Weddell Sea [40,41], but the anomalies if correctly identified [42] may record creation of smaller, older pieces of ocean floor. At an estimated spreading rate of 0.6 $\mathrm{cm} / \mathrm{yr}$ [40], approximately $250 \mathrm{~km}$ of Weddell sea-floor would have been created between M29 $(160 \mathrm{Ma})$ and M1 (122 Ma); this small motion is 
outside the resolution of the paleomagnetic data.

Recent geophysical investigations in the Weddell Sea [41] have found two collinear basement structures; the Andenes Escarpment and the Explora Escarpment. Kristoffersen and Haugland [41] suggest that these two linear basement highs are mid-Jurassic rift-related structures and form a continuous basement ridge across the Weddell Sea. This interpretation would preclude post-rift motion between East Antarctica and Weddellia. Given the differences in basement morphology, structure and magnetic signature between the lineaments and the uncertainty in age, we feel that the Andenes and Explora Escarpments have not been conclusively proven to be the same feature and of mid-Jurassic age.

Our interpretation implies that rigid or mosaic Weddellia moved sinistrally $2500 \mathrm{~km}$ from the Early to mid-Cretaceous along the EWM/East Antarctic boundary, i.e., $10 \mathrm{~cm} / \mathrm{yr}$, possibly along the same transform boundary along which $650 \mathrm{~km}$ of dextral motion is suggested to have occurred between the Middle Jurassic and Early Cretaceous. The fast rate of motion along the Weddellia/East Antarctica boundary could be lessened if sea-floor spreading was initiated in the Weddell Sea prior to $122 \mathrm{Ma}$ and was not paleomagnetically discernible. The postulated motion of Weddellia is equivalent to a clockwise rotation of $30^{\circ}$ about a rotation pole located near the northern tip of the Antarctic Peninsula. Previously we proposed a clockwise rotation of $15-20^{\circ}$ for the combined AP and EWM blocks [14]. Delay of this rotation until 122 to $100 \mathrm{Ma}$ as suggested by our new data, however, requires a larger rotation to compensate for the earlier dextral relative movement of Weddellia with regard to East Antarctica.

A more complex opening history of the Weddell Sea is required if mosaic Weddellia (Fig. 4d) is correct. Apart from the sinistral motion along the EWM block's eastern boundary with East Antarctica, an additional $1000 \mathrm{~km}$ of dextral transcurrent motion would be needed on the EWM/AP boundary between the Early Cretaceous and mid-Cretaceous.

\section{Conclusions}

In conclusion, at least three of the West Antarctic structural blocks (AP, EWM, and TI) appear to have acted as a paleomagnetic entity of closely related blocks, Weddellia, whose motion opened the Weddell Sea since the Early Cretaceous. A reconstruction with a rigid Weddellia assumes little or no relative motion between the AP-EWM-TI blocks and creates a very simple scenario for opening the Weddell Sea (Fig. 4a and c) but is near the limit of experimental error in the paleomagnetic data. A reconstruction with a mosaic Weddellia allows motion between its blocks, i.e., AP and EWM blocks (Fig. 4b and d) by strictly using the individual mean poles, but creates a complex opening history for the Weddell Sea. For this second scenario, approximately 1000 $\mathrm{km}$ of dextral motion would be required between the AP and EWM blocks during the 122 to 100 Ma interval (Fig. 4d and e).

In either reconstruction, the EWM block is located north and east of the AP block in the Middle Jurassic and the structural trend of the Ellsworth Mountains remains at a high angle to the Transantarctic Mountains and Cape Fold Belt at this time. Geologic and paleomagnetic data $[4,6,10]$ suggest approximately $90^{\circ}$ of rotation between the Ellsworth Mountains and the Transantarctic Mountains in East Antarctica. Although the Middle Jurassic paleomagnetic results from the AP [13] and EWM [14] blocks do not indicate a $90^{\circ}$ rotation relative to East Antarctica, rotation of the Ellsworth Mountains may have occurred prior to the Middle Jurassic.

The boundary between East Antarctica and Weddellia in either the rigid or mosaic model is broadly a transcurrent fault zone that has had first dextral and then sinistral motion. The first motion was related to the Mozambique and Somali spreading centers moving East Antarctica southward in the Late Jurassic and earliest Cretaceous while Weddellia remained attached to West Gondwanaland. The subsequent sinistral motion, associated with the opening of the Weddell Sea after $122 \mathrm{Ma}$, moved Weddellia into its present position with respect to East Antarctica by the mid-Cretaceous. In the case of mosaic Weddellia, dextral translation is needed between the EWM block and the AP-TI blocks (Fig. 4c-e), in addition to the sinistral motion between mosaic Weddellia and East Antarctica. The actual position of the strike-slip zone or zones seperating Weddellia from East Antarctica must be between 
Pagano Nunatak and the Transantarctic Mountains. This strike-slip zone could be the plate boundary between the southwest Indian Ocean spreading centers and the Pacific Ocean floor. Our tectonic model for either rigid or mosaic Weddellia also suggests that any physiographic connection between the Pacific Ocean and either the Southwest Indian Ocean or the embryonic South Atlantic Ocean was highly restricted until $122 \mathrm{Ma}$. Paleomagnetic poles of Early Cretaceous age from the AP and EWM blocks and of Middle Jurassic age from the TI block are needed to further test the existence of Weddellia in the Mesozoic.

The position of the fifth West Antarctic crustal block, MBL, is unknown for the Jurassic and Early Cretaceous. A "greater" West Antarctica that includes MBL cannot be ruled out but appears unlikely because the Late Cretaceous pole of MBL [12] does not fall on the common apparent polar wander path of either East Antarctica or Weddellia. Without older poles from MBL the question of its Jurassic or Early Cretaceous position cannot be documented.

\section{Acknowledgements}

This work was supported by the Division of Polar Programs, National Science Foundation through grants No. DPP 82-13798 and DPP 8643441 to I.W.D.D. and by the British Antarctic Survey, National Environmental Research Council. We are very grateful to the BAS air unit and to VXE6 Squadron of the U.S. Navy for their logistical support. Special thanks to Chuck Kroger, our mountaineering expert, for helping with the drilling of paleomagnetic cores. Our colleagues in the British Antarctic Survey, Steve Garrett, Robert Pankhurst and Bryan Storey, together with Doyle Watts of the University of Glasgow provided invaluable discussions and constructive criticism.

\section{References}

1 A.L. Du Toit, Our Wandering Continents, 366 pp., Oliver and Boyd, Edinburgh, 1937.

2 R.S. Dietz and W.P. Sproll, Fit between Africa and Antarctica: a continental dirft reconstruction, Science 167 . $1612-1614,1970$.

3 I.O. Norton and J.G. Slater, A model for the evolution of the Indian Ocean and the breakup of Gondwanaland, J. Geophy. Res. 84, 6803-6830, 1979.
4 J.M. Schopf, Ellsworth Mountains: position in West Antarctica due to sea-floor spreading, Science 164, 63-66, 1969.

5 E.J. Jankowski and D.J. Drewry, The structure of West Antarctica from geophysical studies, Nature 291, 17-21, 1981.

6 I.W.D. Dalziel and D.H. Elliot, West Antarctica: problem child of Gondwanaland, Tectonics 1, 3-19, 1982.

7 I.W.D. Dalziel, S.W. Garrett, A.M. Grunow, R.J. Pankhurst, B.C. Storey and W.R. Vennum, The EllsworthWhitmore Mountains crustal block: its role in the tectonic evolution of West Antarctica, in: Gondwana Six: Structure, Tectonics, and Geophysics, G.D. McKenzie, ed., Am. Geophys. Union, Geophys. Monogr. 40, 173-182, 1987.

8 B.C. Storey, I.W.D. Dalziel, S.W. Garrett, A.M. Grunow, R.J. Pankhurst and W.R. Vennum, West Antarctica in Gondwanaland: crustal blocks, reconstruction and break-up processes, Tectonophysics, in press, 1987.

9 D.H. Elliot, Tectonics of Antarctica: a review, Am. J. Sci. 275-A, 45-106, 1975.

10 D.R. Watts and A.M. Bramall, Paleomagnetic evidence for a displaced terrain in western Antarctica, Nature 293, 638-641, 1981

11 C.H. Scharnberger and L. Sharon, Paleomagnetism of rocks from Graham Land and western Ellsworth Land, Antarctica, in: Antarctic Geoscience, C. Craddock, ed., pp. 371-375, University of Wisconsin Press, Madison, Wisc., 1982.

12 G.W. Grindley and P.J. Oliver, Paleomagnetism of Cretaceous volcanic rocks from Marie Byrd Land, Antarctica, in: Antarctic Earth Science, R.L. Oliver et al., eds., pp. 573-578, Australian Academy of Science, Canberra, A.C.T., 1983.

13 S.K. Longshaw and D.H. Griffiths, A paleomagnetic study of Jurassic rocks from the Antarctic Peninsula and its implications, J. Geol. Soc. London 140, 945-954, 1983.

14 A.M. Grunow, I.W.D. Dalziel and D.V. Kent, EllsworthWhitmore Mountains crustal block, western Antarctica: new paleomagnetic results and their tectonic significance, in: Gondwana Six: Structure, Tectonics, and Geophysics, G.D. McKenzie, ed., Am. Geophys. Union, Geophys. Monogr. 40, 161-172, 1987.

15 S.W. Garrett, L.D.B. Herrod and D.R. Mantripp, Crustal structure of the area around Haag Nunataks, West Antarctica: new aeromagnetic and bedrock elevation data, in: Gondwana Six: Structure, Tectonics, and Geophysics, G.D. McKenzie, ed., Am. Geophys. Union, Geophys. Monogr. 40, 109-116, 1987.

$16 \mathrm{I}$. Millar and R.J. Pankhurst, $\mathrm{Rb} / \mathrm{Sr}$ geochronology in the region between the Antarctic Peninsula and the Transantarctic Mountains: Haag Nunataks and Mesozoic granitoids, in: Gondwana Six: Structure, Tectonics, and Geophysics, G.D. McKenzie, ed., Am. Geophys. Union, Geophys. Monogr. 40, 151-160, 1987.

17 B.C. Storey and I.W.D. Dalziel, Aspects of the structural and tectonic history of the Ellsworth-Thiel Mountains ridge, West Antarctica, in: Gondwana Six: Structure, Tectonics, and Geophysics, G.D. McKenzie, ed., Am. Geophys. Union, Geophys. Monogr. 40, 117-128, 1987.

18 W.R. Vennum and B.C. Storey, Petrology and tectonic setting of granitic rocks from the Ellsworth-Whitmore 
crustal block and Thiel Mountains, West Antarctica, in: Gondwana Six: Structure, Tectonics, and Geophysics, G.D. McKenzie, ed., Am. Geophys. Union, Geophys. Monogr. 40, 139-150, 1987.

19 B.C. Storey and D.I.M. Macdonald, Sedimentary rocks of the Ellsworth-Thiel Mountains Ridge and their regional equivalents, Br. Antarct. Surv. Bull. 76, in press, 1987.

20 C. Craddock, The East Antarctic-West Antarctic boundary between the ice shelves: a review, in: Antarctic Earth Science, R.L. Oliver, et al., eds. pp. 94-97, Australian Academy of Science, Canberra, A.C.T., 1983.

21 W.C. Mclntosh, P.R. Kyle, E.M. Cherry, and H.C. Noltimier, Paleomagnetic results from the Kirkpatrick Basalt Group, Victoria Land, Antarct. J. U.S. 17, 20-22, 1982.

22 M. Funaki, Paleomagnetic investigation of Ferrar dolerite in McMurdo Sound, Antarctica, Antarct. Rec. 77, 20-32, 1982.

23 J.D.A. Zijderveld, A.C. demagnetization of rocks: analysis of results, in: Methods of Paleomagnetism, D.W. Collison, K.M. Creer and S.K. Runcorn, eds., pp. 254-286, Elsevier, Amsterdam, 1967.

24 J.L. Kirschvink, The least-square line and plane analysis of paleomagnetic data, Geophys. J. R. Astro. Soc. 62, 699-_ 718 . 1980.

25 The term "Weddellian Province" has been proposed by Zinsmeister [26] for a biogeographical province extending from South America to Australasia in the Late Cretaceous - Eocene and including the entire area of our proposed tectonic province "Weddellia".

26 W.J. Zinsmeister. Biographic significane of the Late Mesozoic and Early Tertiary Molluscan Faunas of Seymour Island (Antarctic Peninsula) to the final breakup of Gondwanaland, Proc. Annu. Biol. Colloq. Select. Pap. 371, 349-355, 1979.

27 E. Irving and G.A. Irving, Apparent polar wander paths Carboniferous through Cenozoic and the assembly of Gondwana, Geophys. Surv. 5, 141-188, 1982.

28 L.A. Lawver, J.G. Sclater and L. Meinke, Mesozoic and Cenozoic reconstructions of the South Atlantic. Tectonophysics 114, 233-254, 1985 .

29 A. Brock, Paleomagnetism of Africa and Madagascar, Geodyn. Ser. 2, 65-76, 1981.

30 P.W. Schmidt, The non-uniqueness of the Australian Mesozoic paleomagnetic pole position, Geophys. J.R. Astron. Soc. 47, 285-300, 1976.
31 D.A. Gust, K.T. Biddle, D.W. Phelps and M.A. Uliana, Associated Middle to Late Jurassic volcanism and extension in southern South America, Tectonophysics 116, 223-253, 1985.

32 I.W.D. Dalziel, B.C. Storey, S.W. Garrett, A.M. Grunow, L.D.B. Herrod and R.J. Pankhurst, Extension tectonies and the fragmentation of Gondwanaland, Geol. Soc. London Spec. Publ. on Continental Extensional Tectonics, in press, 1987.

33 E.S.W. Simpson, J.G. Slater, B. Parsons, I. Norton and L. Meinke, Mesozoic magnetic lineations in the Mozambique Basin, Earth Planet. Sci. Lett. 43, 260-264, 1979.

34 J. Segoufin and P. Patriot, Existence d'anomalies mésozoiques dans le bassin de Somalie, implications pour les rélations Afrique-Antarctique-Madagascar, C.R. Acad. Sci. Paris, Sér. B291, 85-88, 1980.

35 P.D. Rabinowitz, M.F. Coffin and D. Dalvey, The separation of Madagascar and Africa, Science 220, 67-69, 1983.

36 D.L. Schmidt and P.D. Rowley, Continental rifting and transform faulting along the Jurassic Transantarctic rift, Antarctica, Tectonics 5, 279-291, 1986.

37 K.S. Kellogg and R.L. Reynolds, Paleomagnetic results from the Lassiter Coast, Antarctica, and a test for oroclinal bending of the Antarctic Peninsula, J. Geophys. Res. 83, 2293-2299, 1978.

38 D.R. Watts, G.C. Watts and A.M. Bramall, Cretaceous and early Tertiary paleomagnetic results from the Antarctic Peninsula, Tectonics 3, 333-346, 1984.

39 D.V. Kent and F.M. Gradstein, A Cretaceous and Jurassic geochronology, Geol. Soc. Am. Bull. 96, 1419-1427, 1985.

40 J.L. LaBrecque and P. Barker, The age of the Weddell Basin, Nature 290, 489-492, 1981.

41 Y. Kristoffersen and K. Haugland, Geophysical evidence for the East Antarctic plate boundary in the Weddell Sea. Nature 322, 538-541, 1986.

42 A.K. Martin and C.J.H. Hartnady, Plate tectonic development of the southwest Indian Ocean: a revised reconstruction of East Antarctica and Africa, J. Geophys. Res. 91, 4767-4786, 1986

43 R.A. Fisher, Dispersion on a sphere, Proc. R. Soc. London, Ser. A 217, 295-305. 1953. 